\title{
Transabdominal ultrasonografi ved inflammatorisk tarmsykdom
}

\author{
Sammendrag \\ Bakgrunn. Transabdominal ultrasono- \\ grafi er de siste 15 årene blitt brukt \\ i økende grad til å vurdere pasienter \\ med inflammatorisk tarmsykdom. Ved \\ Medisinsk avdeling, Haukeland univer- \\ sitetssykehus utføres om lag 300 slike \\ undersøkelser årlig. Artikkelen gir en \\ oversikt over bruk av ultrasonografi ved \\ ulcerøs kolitt og Crohns sykdom.
}

Materiale og metode. Artikkelen er basert på ikke-systematiske søk i PubMed samt materiale fra vårt eget litteraturarkiv.

Resultater. Ved Crohns sykdom ses ofte strukturendringer i og fortykkelse av tarmveggen med transabdominal ultrasonografi. Ved ulcerøs kolitt er strukturen ofte bevart, sykdommen begrenset til tykktarmen og veggen lett eller moderat fortykket. Sensitiviteten og spesifisiteten for å oppdage inflammatorisk tarmsykdom ligger rundt henholdsvis $85 \%$ og $95 \%$. For Crohns sykdom alene er tilsvarende funn $88 \%$ og $93 \%$. Hos pasienter med komplisert Crohns sykdom er transabdominal ultrasonografi best til påvisning av stenoser (sensitivitet 74-100\%, spesifisitet $91-100 \%$ ) og noe dårligere til å påvise fistler (sensitivitet $71 \%$, spesifisitet $96 \%$ ) og abscesser (sensitivitet $81 \%$, spesifisitet $93 \%$ ). Lokal hyperemi i tarmveggen taler for aktiv inflammasjon og kan påvises med fargedoppler.

Fortolkning. Transabdominal ultrasonografi er nyttig ved primærutredning og oppfølging av pasienter med inflammatorisk tarmsykdom. At klinikerne selv utfører undersøkelsen, gir potensielt mer effektiv og billigere primærutredning og oppfølging av pasienter med inflammatorisk tarmsykdom.

\author{
Erlend Fjell Nævdal † \\ Kim Nylund \\ kim.nylund@med.uib.no \\ Odd Helge Gilja \\ Institutt for indremedisin \\ Universitetet i Bergen \\ 5021 Bergen \\ og \\ Nasjonalt senter for gastroenterologisk \\ ultrasonografi \\ Medisinsk avdeling \\ Haukeland universitetssykehus \\ Bergen
}

Insidensen og prevalensen for Crohns sykdom og ulcerøs kolitt er høy i Skandinavia, Storbritannia og Nord-Amerika, og økende i andre land med vestlig livsstil (1). Transabdominal ultrasonografi av tarm er en ikkeinvasiv, lett tilgjengelig undersøkelsesmetode som de siste 15 årene er blitt benyttet $i$ diagnostikk av inflammatorisk tarmsykdom. I motsetning til en del andre undersøkelsesmetoder, som CT, MR og røntgen av tynntarm med sonde, kan klinikeren selv utføre ultrasonografi og bruke metoden til å undersøke sine «egne» pasienter. Ved Medisinsk avdeling, Haukeland universitetssykehus er ultralydundersøkelser av pasienter med inflammatorisk tarmsykdom inkludert i den daglige rutinen, på linje med endoskopiundersøkelser. Årlig utfører vi ca. 300 undersøkelser på denne typen pasienter.

I denne artikkelen ønsker vi å belyse hvordan ultrasonografi kan anvendes til å vurdere pasienter med inflammatorisk tarmsykdom. Hovedfokus er Crohns sykdom, men ulcerøs kolitt blir også omtalt.

\section{Materiale og metode}

Artikkelen er basert på en gjennomgang av artikler i vårt eget litteraturarkiv, noen relevante referanser hentet fra disse artiklene og våre egne erfaringer med ultrasonografi ved inflammatorisk tarmsykdom. Det er også gjort ikke-systematiske litteratursøk i PubMed, som resulterte $i$ et skjønnsmessig utvalg av artikler.

\section{Pasientforberedelser}

Ultralydundersøkelser av pasienter med inflammatorisk tarmsykdom krever vanligvis ingen forberedelser. Det er en fordel om pasienten møter fastende ( $>4$ timer) slik at det blir mindre luft og innhold i tarmen og dermed bedre innsyn. Inntak av klare væsker (hydrosonografi) før undersøkelsen kan gjøre det lettere å fremstille bakre tarmvegg og se intraluminale prosesser. To til tre glass vann er tilstrekkelig for undersøkelse av ventrikkel og duodenum mens ved undersøkelse av tynntarm anbefales opptil 21 polyetylenglykolløsning peroralt eller via sonde $(2,3)$. Undersøkelsen utføres vanligvis i ryggleie, men både skrått sideleie og stående stilling kan noen ganger bedre innsynet.

Ultralydmodaliteter og normalfunn Undersøkelsen innledes med orienterende B-mode skanning av hele abdomen ved bruk av et 3,5-5 MHz kurvilineært lydhode (4). Man kan da vurdere ulike abdominale organer, eventuelt finne patologi som ligger dypere i buken enn rekkevidden til høyfrekvente lydhoder $(7,5-14 \mathrm{MHz})$ og dessuten se større patologiske tarmlesjoner. Lavfrekvente lydhoder $(<4 \mathrm{MHz})$ kan vanligvis ikke brukes til å vurdere detaljer som for eksempel lagdeling og små blodkar i tarmveggen. Undersøkelsen utføres derfor etterpå med høyfrekvente lydhoder. Dette gir bedre bildeoppløsning, og fremstillingen av tarmveggen optimaliseres (5).

Med høyfrekvent ultrasonografi ses vanligvis fem lag i en normal tarmvegg $(6,7)$ enten man vurderer veggen fra serosa (transdusernære tarmvegg) eller fra mucosasiden (dorsale, transduserfjerne tarmvegg) (fig 1). Hvis det ses færre eller flere enn fem vegglag, kan dette indikere sykdom. For å undersøke om et tarmavsnitt er patologisk eller ikke, måles blant annet tarmveggens tykkelse. Lagdelingen i tarmveggen gjør at det oppstår overgangsekko når ultralydbølgene passerer fra et vegglag til et annet. Tykkelsen av tarmveggen måles oftest av den ventrale, transdusernære tarmveggen og vil da inkludere lagene $2-4$, siden lag 1 i dette tilfellet er overgangsekkoet mellom lumen og mucosa. Overgangsekkoet mellom serosa og muscularis propria vil dessuten dekke en liten del av muscularis propria og således føre til at ventralsiden fremstår noe tynnere

\section{Hovedbudskap}

- Ultralyd kan være nyttig til primærutredning og oppfølging av pasienter med inflammatorisk tarmsykdom

- Vi mener at det gagner pasientene hvis norske klinikere i større utstrekning bruker ultrasonografi ved inflammatorisk tarmsykdom 
enn dorsalsiden med ultralyd. Siden dorsalsiden ofte er vanskelig å fremstille, velger man imidlertid ventralsiden som utgangspunkt for målingene.

I ileum anses veggen som patologisk fortykket dersom den måler mer enn $3 \mathrm{~mm}(8$, 9). I tykktarmen varierer verdiene mellom normal og fortykket vegg fra 2,0 $\mathrm{mm}$ til 3,5 $\mathrm{mm}$ med økende tykkelse jo lengre distalt man kommer. Blodkar i tarmveggen er vanligvis så små at de ikke kan ses i B-mode ved transabdominal undersøkelse, men ved hjelp av fargedoppler kan blodstrøm fremstilles i disse karene (10). Ved bruk av høyfrekvente lydhoder må innstillingen justeres slik at lave blodstrømshastigheter kan oppdages. Veggfilteret må settes lavt, og hastighetsskalaen bør ligge rundt $2-8 \mathrm{~cm}$ per sekund. Grunnet bevegelsesartefakter bør pasienten holde pusten under dopplerundersøkelsen.

\section{Primærdiagnostikk}

Crohns sykdom er karakterisert ved transmural betennelse i tarmveggen. Dette medfører at tarmveggens lagdeling hos pasienter med aktiv sykdom ofte er forandret, eventuelt helt borte. I stedet ses gjerne et kontinuerlig mørkere ekko gjennom hele tarmveggen (11). Veggen er ofte betydelig fortykket $\mathrm{i}$ de affiserte områdene, og i uttalte tilfeller kan man måle tykkelser opptil $1,5 \mathrm{~cm}$ (12). Crohns sykdom kan gi flekkvise manifestasjoner i hele gastrointestinalkanalen, men hos de fleste er funnene begrenset til tynn- og/eller tykktarm. Nesten halvparten av pasientene har affeksjon av terminale ileum (13), og sykdom er lettere å påvise hos disse sammenliknet med pasienter som har affeksjon av dypereliggende tarmavsnitt (14).

Ulcerøs kolitt lokalisert til rectum kan være vanskelig å påvise med transabdominal ultralyd. Man kan følge colon fra sigmoideum til coecum med ultralyd og således påvise om det foreligger sigmoiditt, venstresidig kolitt, subtotal- eller totalkolitt. Siden affeksjonen vanligvis er kontinuerlig fra rectum og videre proksimalt ved ulcerøs kolitt, er det lettere å kartlegge utbredelsen enn ved Crohns sykdom der sykdommen kan være lokalisert til flere atskilte områder i en ellers normal tarm. Ved ulcerøs kolitt finner man vanligvis ikke veggtykkelse over $6 \mathrm{~mm}$ ved transabdominal ultrasonografi (15), og lagdelingen i tarmveggen er ofte bevart (11). Dette kommer av at inflammasjonen som regel ikke går lenger inn $\mathrm{i}$ tarmveggen enn til submucosa. Lag 2 og 3, som hovedsakelig svarer til henholdsvis mucosa og submucosa, er ofte fortykket ved ulcerøs kolitt (11) (fig 2). Ved mild og overflatisk Crohns sykdom kan man noen ganger gjøre tilsvarende funn med bevart lagdeling og mindre uttalt veggtykkelse.

I en studie med 487 pasienter undersøkt med transabdominal ultralyd, ble inflammatorisk tarmsykdom påvist med $85 \%$ sensitivitet og $95 \%$ spesifisitet (16). Sensitiviteten for Crohns sykdom og ulcerøs kolitt var henholdsvis $88 \%$ og $84 \%$ i denne studien. I en

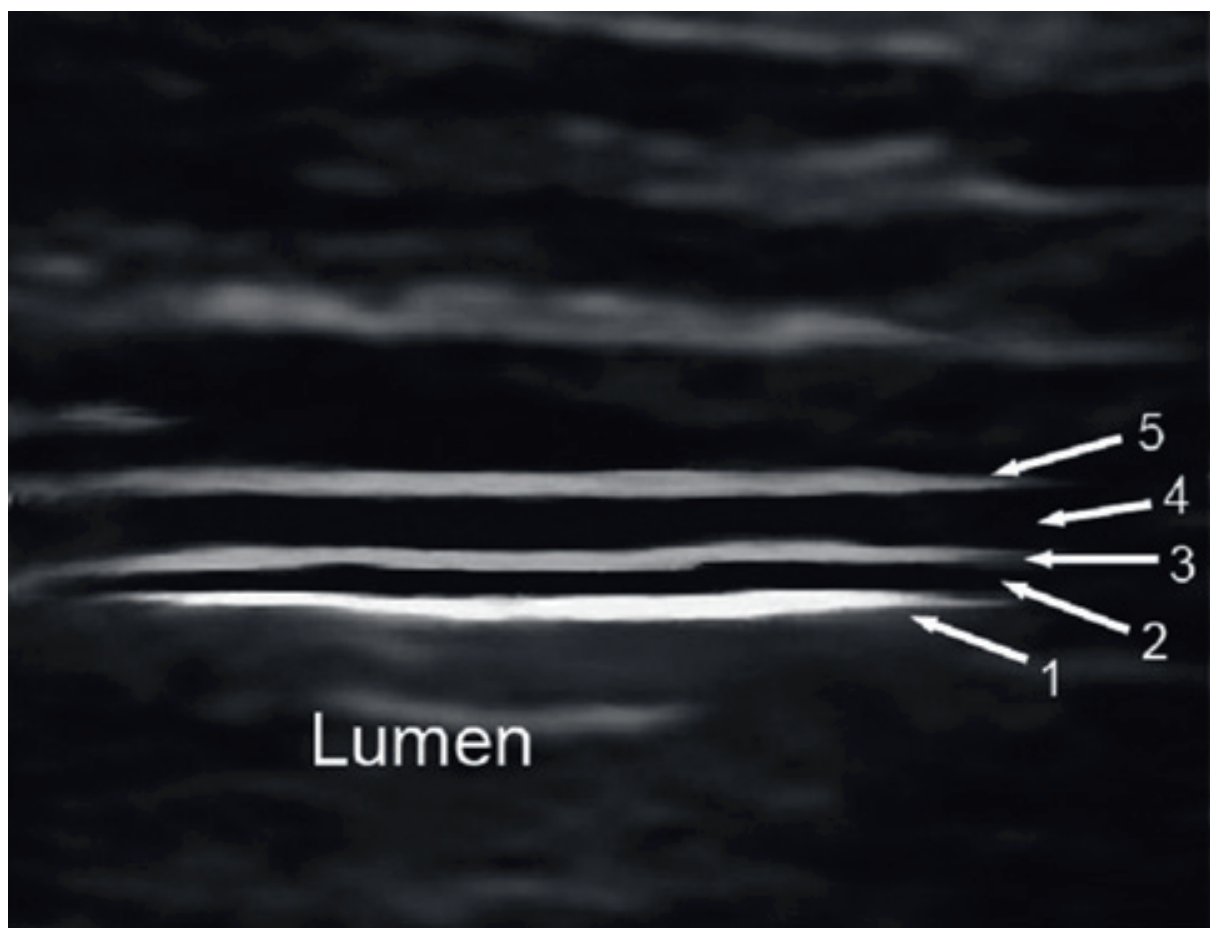

Figur 1 Et forstørret og manipulert høyfrekvent ultralydbilde som viser den karakteristiske femdelte lagdelingen i en normal tarmvegg. De lagene som gir hvit farge er hyperekkogene, mens de svarte lagene er hypoekkogene. Lag 1 betegner overgangsekkoet mellom tarmlumen og mucosa. Lag 2 gjenspeiler den dype mucosa. Lag 3 viser submucosa samt overgangsekkoet til mucosa. Lag 4 representerer resten av muscularis propria, mens lag 5 viser overgangsekkoet mellom serosa og muscularis propria metaanalyse fra 2005 fremkom det at sensitiviteten og spesifisiteten for å oppdage Crohns sykdom ved bruk av ultralyd var henholdsvis $88 \%$ og $93 \%$, med grenseverdi for normal/patologisk tarmveggtykkelse på $3 \mathrm{~mm}$ (8). Sensitiviteten og spesifisiteten var henholdsvis $75 \%$ og $97 \%$ hvis grensever- dien ble satt til $4 \mathrm{~mm}$. I metaanalysen konkluderte man med at ultralyd er velegnet til både å bekrefte og å utelukke Crohns sykdom i en populasjon tilsvarende det man kan finne $\mathrm{i}$ annenlinjetjenesten.

Ultralyd har vist seg å være et nyttig verktøy sammen med endoskopiske undersøkel-

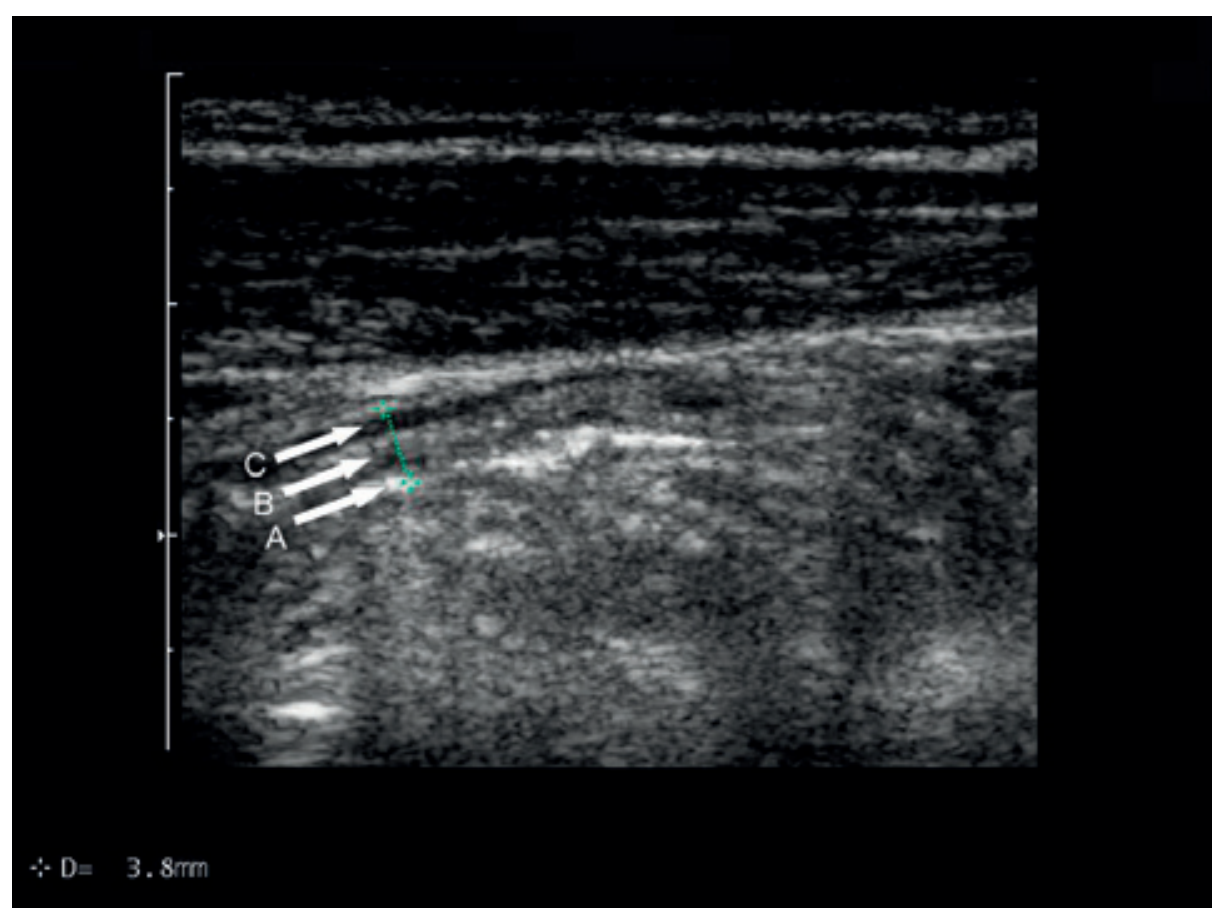

Figur 2 Colon transversum (B-mode, 7,5 MHz) hos pasient med ulcerøs kolitt. Veggen er fortykket til 3,8 mm, mens lagdelingen er bevart. Den patologiske tykkelsen skyldes i dette tilfellet hovedsakelig endringer $\mathrm{l} \operatorname{lag} 3$. Pil $A=\operatorname{lag} 1$, pil $B=\operatorname{lag} 3$ og pil $C=\operatorname{lag} 4$ 


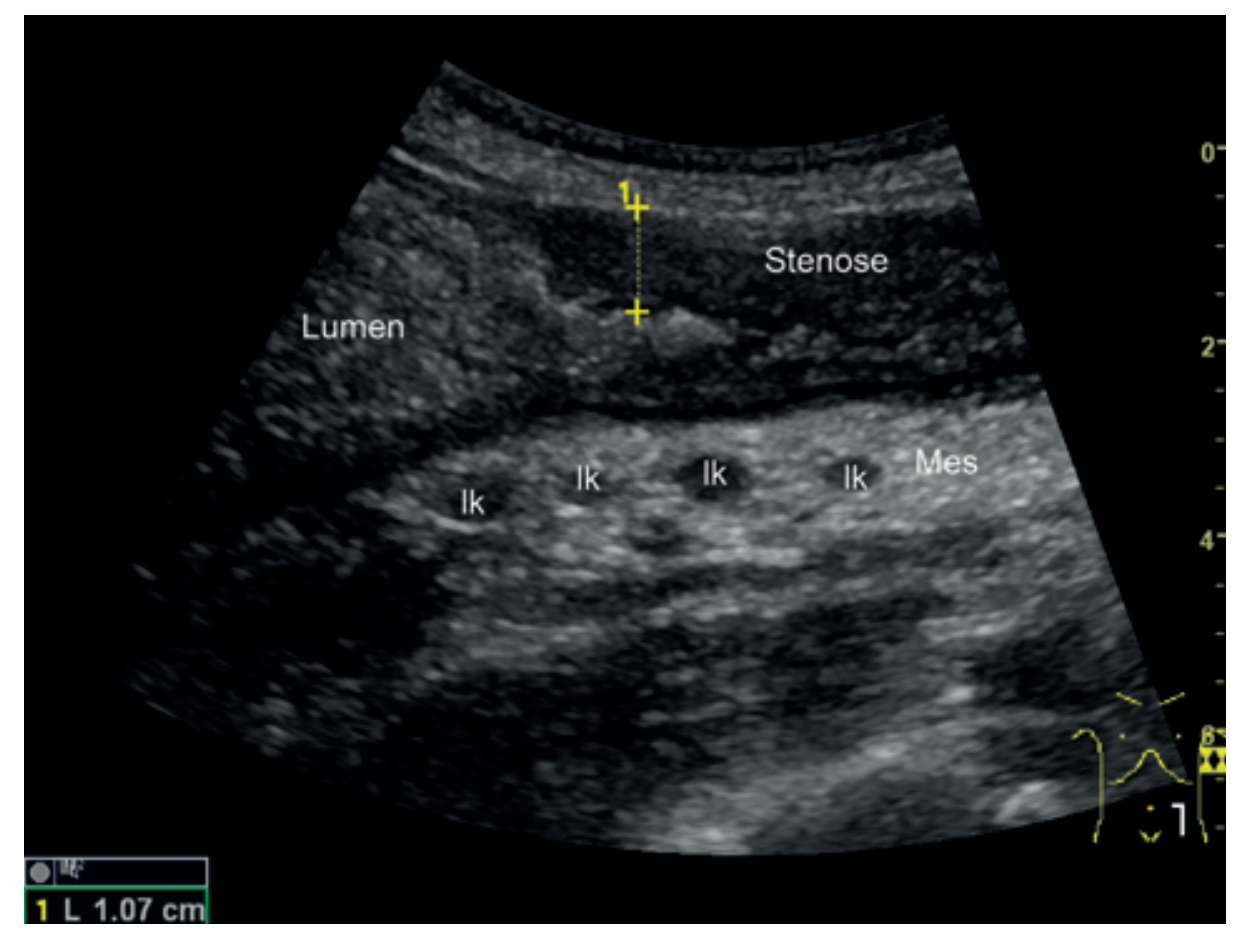

Figur 3 Pasient med Crohns sykdom. Bildet er tatt i nedre venstre kvadrant (B-mode, $4 \mathrm{MHz}$ ) og viser et stenotisk parti i colon descendens med prestenotisk dilatasjon. Tarmveggen er fortykket med redusert lagdeling. Flere lymfeknuter (lk) kan ses i mesenteriet (Mes)

ser innen primærdiagnostikken av inflammatorisk tarmsykdom. I erfarne hender kan en ultralydundersøkelse være en enklere og mer tilgjengelig metode enn CT og MR til å vurdere tarmveggen. Ultralyd er i flere studier sammenliknet med andre bildedannende metoder. I én studie sammenliknet man ultralyd med kontrastrøntgen, immunoscintigrafi og CT til påvisning av Crohns sykdom i tynntarm (17). Man fant at ultralyd hadde diagnostisk nøyaktighet på 90,4\% mens den for CT og immunoscintigrafi var

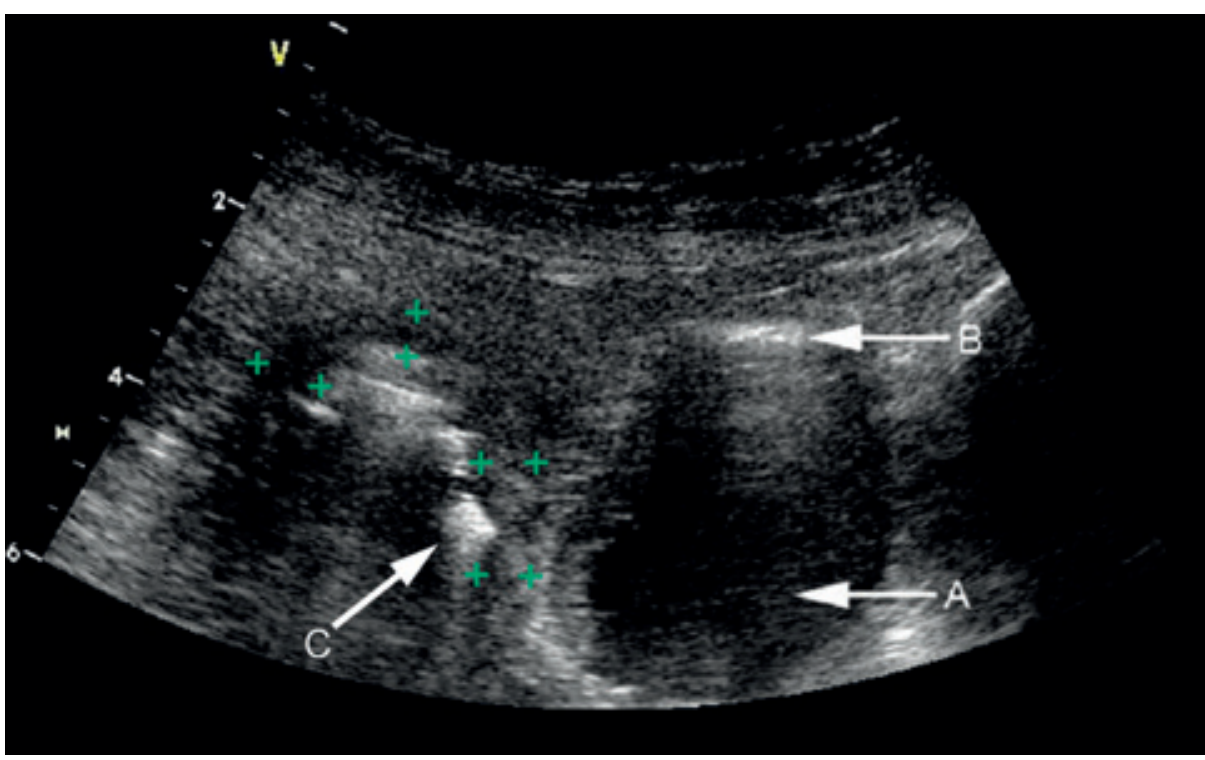

Figur 4 Pasient med Crohns sykdom (B-mode, $4 \mathrm{MHz}$ ). Pil A viser urinblæren og pil B luft øverst i blæren, noe som antyder at tarmgass har passert til blæren gjennom en enterovesikal fistel. Kryssene markerer sigmoideums vegg, som er betydelig fortykket. Pil C viser luft i sigmoideum. Operasjon bekreftet mistanken om fistel mellom sigmoideum og urinblæren
Stenoser kan forekomme ved Crohns sykdom (fig 3). Man ser da ofte betydelig fortykket vegg og avsmalnet lumen og en prestenotisk utvidelse. Den fortykkede tarmveggen $i$ stenosen har liten eller ingen motilitet. Bortfall av lagdeling i stenosen indikerer ødem i tarmveggen og sannsynlig akutt inflammasjon, mens mer bevart lagdeling kan indikere fibrose (18). Det er viktig for valg av behandling å vite om den fortykkede veggen i en stenose skyldes hovedsakelig aktiv inflammasjon eller fibrose. Ved aktiv inflammasjon kan pasienten ha nytte av medisinsk behandling, mens kirurgi vanligvis er indisert ved kroniske betennelsesforandringer og fibrose (18). Hvis man ved hjelp av fargedoppler ser rikelig med kar i stenoseområdet, tolkes det som et uttrykk for inflammatorisk aktivitet. Da kan medikamentell behandling være verdt å forsøke. Ultralyd er i flere studier brukt til å påvise stenoser hos pasienter med Crohns sykdom. I disse studiene har ultralyd en sensitivitet på $74-100 \%$ og en spesifisitet på 91-100\% $(9,14,19)$.

Danning av fistler er en hyppig komplikasjon ved Crohns sykdom. Fistlene utgår fra tarmveggen og kommuniserer med andre tarmsegmenter, mesenteriet eller andre strukturer som urinblære, vagina eller perineum (12). Ved ultrasonografi ses fistler ofte som avlange hypoekkogene områder. Små, hyperekkogene flekker kan noen ganger ses innenfor slike områder på grunn av innhold av luft, debris eller avføring i fistelen $(9,20)$. I noen tilfeller kan man sannsynliggjøre fisteldanning til tross for at man på ultralyd ikke ser fistelen. Dette gjelder spesielt for enterovesikale fistler (fig 4).

Intraabdominale abscesser er en annen kjent komplikasjon ved Crohns sykdom (fig 5). De oppstår vanligvis sekundært til fistulerende sykdom eller etter kirurgiske inngrep (21). Med ultralyd ser man hypoekkogene områder med uregelmessige avgrensninger. Små, hyperekkogene lesjoner kan noen ganger forekomme inne i abscesshuler på grunn av luft eller debris (12). Maconi og medarbeidere konkluderte i 2003 med at transabdominal ultralyd kan være et like godt førstevalg til å påvise fistler og abscesser ved Crohns sykdom som kontrastrøntgen eller CT (22). Fistler ble påvist med $71 \%$ sensitivitet og $96 \%$ spesifisitet, mens abscesser ble påvist med $81 \%$ sensitivitet og $93 \%$ spesifisitet. Våre erfaringer er at dype abscesser er best å visualisere med CT, mens overflatiske og små abscesser ses best med ultralyd.

Ved ulcerøs kolitt finner man sjelden stenoser, fistler eller abscesser. Toksisk kolitt forekommer sjeldnere enn før, men dette er en alvorlig tilstand som kan resultere i tarmperforasjon. Vanligvis diagnostiseres denne tilstanden med røntgen oversikt abdomen, men ultralyd er et strålefritt alternativ til å oppdage og eventuelt følge opp denne tilstanden (23). 


\section{Behandlingsovervåkning og sykdomsaktivitet}

Allerede i 1984 kunne man med transabdominal ultrasonografi påvise betydelig reduksjon i veggtykkelsene hos pasienter med Crohns sykdom i etterkant av medisinsk behandling (24). I en annen studie ble det gjort tilsvarende funn etter akutt medisinsk behandling hos pasienter med ulcerøs kolitt (25). Metoden kan også benyttes til å følge pasienter med Crohns sykdom postoperativt. Risikoen for tilbakefall er høy hos dem som ikke har fått reduksjon i veggtykkelsene 6-12 måneder etter operasjon $(26,27)$.

Inflammatorisk tarmsykdom er assosiert med nydanning av blodkar og økt blodtilførsel $i$ veggen til de betente tarmsegmentene (28). Fargedoppler kan brukes til å vurdere kartetthet semikvantitativt (fig 6) og er til en viss grad assosiert med sykdomsaktivitet $(29,30)$. Spalinger og medarbeidere fant at pasienter med inaktiv sykdom (Crohn's disease activity index $($ CDAI $)<150)$ hadde signifikant mindre kartetthet $(\mathrm{p}<0,001)$ enn pasienter med aktiv sykdom (CDAI $>150)$ (29). Fargedoppler anbefales hovedsakelig til å følge endringer av blodsirkulasjon i tarmveggen over tid hos den enkelte pasient.

De fleste pasientene med inflammatorisk tarmsykdom lever med sykdommen gjennom store deler av livet, og sykdomsforløpet kan være svært varierende. For klinikeren er det derfor viktig å ha et praktisk verktøy til å vurdere sykdomsaktivitet. En sammenliknende studie mellom ultralyd og MR til påvisning av Crohns sykdom i aktiv fase viste at begge modalitetene hadde god sensitivitet (87\%) til å oppdage aktiv inflammasjon (31). MR hadde derimot noe lavere spesifisitet enn ultralyd ( $71 \%$ for MR og $100 \%$ for ultralyd). Hos pasienter med Crohns sykdom har man også undersøkt om kombinasjon av veggtykkelse, lengde av fortykket tarmsegment, tap av lagdeling eller funn med fargedoppler kan relateres til CDAIskår, men korrelasjonene var i noen studier ikke optimale $(32,33)$. Derimot var sammenhengen mellom ultralydfunn og endoskopisk aktivitet bedre (32). Imidlertid har man $\mathrm{i}$ andre studier påvist god korrelasjon mellom CDAI-skår og ultralydfunn $(29,34)$.

\section{Kostnader}

Vi har ikke funnet studier der man spesifikt har undersøkt kostnadseffektivitet ved bruk av transabdominal ultrasonografi ved inflammatorisk tarmsykdom. Imidlertid er kostnader per undersøkelse generelt lavere ved ultralyd, fordi ultralydmaskiner er billigere i innkjøp enn CT- og MR-maskiner, er mindre plasskrevende og krever ikke ytterligere arbeidsstasjoner for senere gjennomgang av undersøkelsene. Driftskostnadene for ultralyd er også lavere enn for CT, MR, ileokoloskopi og scintigrafi fordi det krever mindre personell (35). Siden nøyaktigheten ved transabdominal ultrasonografi av tarm er tilsvarende eller bedre enn MR, CT og

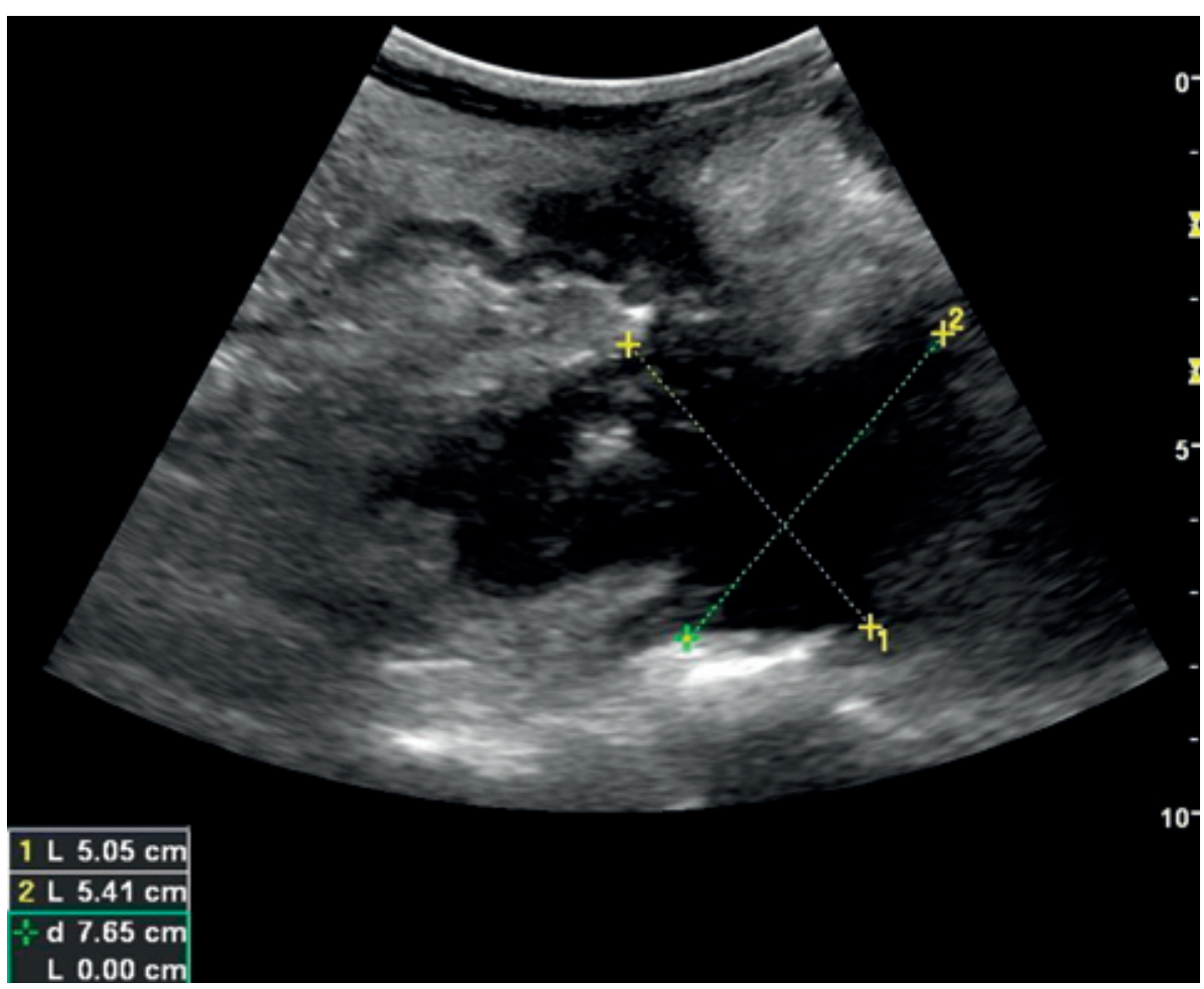

Figur 5 Pasient med Crohns sykdom. Bildet er tatt i høyre regio iliaca (B-mode, $4 \mathrm{MHz}$ ). En hypoekkogen lesjon på 5,0 · 5,4 cm nær et tarmavsnitt ble tolket som en abscesshule med reaksjon i omliggende vev. Funnet ble bekreftet med CT og operasjon scintigrafi (36), kan det ofte erstatte slike undersøkelser og dermed gi innsparinger.

\section{Konklusjon}

Bildekvaliteten på ultralydskannere er betydelig høynet de siste 10-15 år, og dette bidrar til bedret diagnostikk av patologiske forandringer i tarm. Ultralydundersøkelsen har sine begrensninger, men i flere studier har ultralyd vist seg å være nyttig både ved Crohns sykdom, ulcerøs kolitt og andre tarmsykdommer.

Ved primærdiagnostikk av inflammatorisk tarmsykdom har metoden vist høy sen-

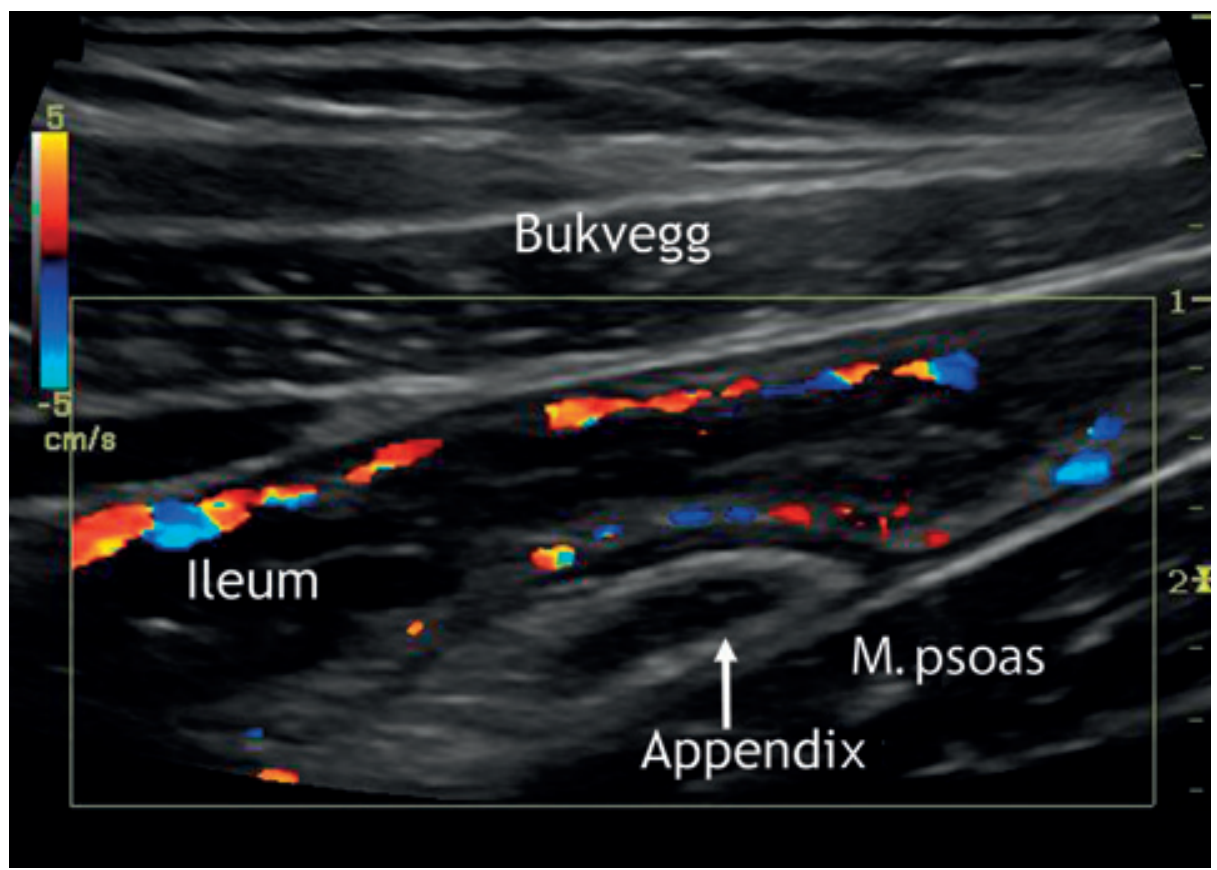

Figur 6 Pasient med Crohns sykdom. Bildet er tatt i høyre regio iliaca (B-mode $8 \mathrm{MHz}$, doppler 5,0 MHz) og viser fortykket vegg i terminale ileum og rikelig med fargedopplersignaler i submucosa. Appendix (hvit pill ligger mellom terminale ileum og psoasmuskelen og har normal veggtykkelse. Her ses det heller ingen fargedopplersignaler i veggen 
sitivitet og spesifisitet. Metoden kan også brukes til å påvise stenoser, fistler og abscesser, noe som kan ha betydning for valg av behandling og oppfølging av pasienter med inflammatorisk tarmsykdom.

Våre erfaringer viser at transabdominal ultralyd er et nyttig redskap ved inflammatorisk tarmsykdom, og vi mener at en slik pasientvennlig og relativt billig metode bør benyttes i enda større grad både ved norske sykehus og i spesialistpraksis (37). Når undersøkelsen utføres av klinikeren selv, enten på poliklinikken eller ved sykesengen på avdelingen, mottas hurtig og viktig informasjon om sykdommens aktivitet og utbredelse.

Vi takker Svein Ødegaard for verdifulle råd ved utarbeiding av dette manuskriptet.

\section{Oppgitte interessekonflikter: Ingen}

\section{Litteratur}

1. Loftus EV jr. Clinical epidemiology of inflammatory bowel disease: Incidence, prevalence, and environmental influences. Gastroenterology 2004; 126 1504-17.

2. Folvik $G$, Bjerke-Larssen $T$, Odegaard $\mathrm{S}$ et al. Hydrosonography of the small intestine: comparison with radiologic barium study. Scand J Gastroenterol 1999: 34: 1247-52

3. Pallotta N, Baccini F, Corazziari E. Contrast ultrasonography of the normal small bowel. Ultrasound Med Biol 1999; 25: 1335-40.

4. Ødegaard S, Gilja OH, Gregersen H. Basic and new aspects of gastrointestinal ultrasonography. Singapore: World Scientific, 2005.

5. Nylund K, Hausken T, Gilja OH. Ultrasound and inflammatory bowel disease. Ultrasound Q 2010; 26: 3-15.

6. Kimmey MB, Martin RW, Haggitt RC et al. Histologic correlates of gastrointestinal ultrasound images. Gastroenterology 1989; 96: 433-41.

7. Wilson SR, Burns PN, Wilkinson LM et al. Gas at abdominal US: appearance, relevance, and analysis of artifacts. Radiology 1999; 210: 113-23.

8. Fraquelli M, Colli A, Casazza G et al. Role of US in detection of Crohn disease: meta-analysis. Radiology 2005; 236: 95-101.

9. Gasche C. Moser G, Turetschek K et al. Transabdominal bowel sonography for the detection of intestinal complications in Crohn's disease. Gut 1999: 44: 112-7

10. Ødegaard S, Kimmey MB, Cheung AHS et al. High frequency endosonography of gastrointestinal arteries: potential and limitations defined in vitro. Eur J Ultrasound 1995; 2: 313-9.

11. Limberg B. Osswald B. Diagnosis and differential diagnosis of ulcerative colitis and Crohn's disease by hydrocolonic sonography. Am J Gastroenterol 1994; 89: $1051-7$

12. Maconi G, Radice E, Greco S et al. Bowel ultrasound in Crohn's disease. Best Pract Res Clin Gastroenterol 2006: 20: 93-112.

13. Gasche C, Scholmerich J, Brynskov J et al. A simple classification of Crohn's disease: report of the Working Party for the World Congresses of Gastroenterology, Vienna 1998. Inflamm Bowel Dis 2000; 6: 8-15

14. Parente F, Maconi G, Bollani S et al. Bowel ultrasound in assessment of Crohn's disease and detection of related small bowel strictures: a prospective comparative study versus $x$ ray and intraoperative findings. Gut 2002; 50: 490-5.

15. Winther KV, Føgh P. Thomsen 00 et al. Inflammatory bowel disease lulcerative colitis and Crohn's disease): diagnostic criteria and differential diagnosis. Drugs Today (Barc) 1998; 34: 935-42.

16. Parente F, Greco S, Molteni M et al. Role of early ultrasound in detecting inflammatory intestinal disorders and identifying their anatomical location within the bowel. Aliment Pharmacol Ther 2003; 18: 1009-16.

17. Tarján Z, Tóth G, Györke T et al. Ultrasound in Crohn's disease of the small bowel. Eur J Radiol 2000; 35: 176-82

18. Maconi G, Carsana L, Fociani P et al. Small bowel stenosis in Crohn's disease: clinical, biochemical and ultrasonographic evaluation of histological features. Aliment Pharmacol Ther 2003; 18: $749-56$.

19. Kohn A, Cerro P, Milite $G$ et al. Prospective evaluation of transabdominal bowel sonography in the diagnosis of intestinal obstruction in Crohn's disease: comparison with plain abdominal film and small bowel enteroclysis. Inflamm Bowel Dis 1999. 5: $153-7$

20. Maconi G, Bollani S, Bianchi Porro G. Ultrasonographic detection of intestinal complications in Crohn's disease. Dig Dis Sci 1996; 41: 1643-8.

21. Steinberg DM, Cooke WT, Alexander-Williams J. Abscess and fistulae in Crohn's disease. Gut 1973; 14: 865-9.

22. Maconi G, Sampietro GM, Parente F et al. Contrast radiology, computed tomography and ultrasonography in detecting internal fistulas and intraabdominal abscesses in Crohn's disease: a prospective comparative study. Am J Gastroenterol 2003: 98: 1545-55.

23. Joseph AE. Ultrasound scanning. Scand J Gastroenterol Suppl 1994; 203: 24-7.

24. Dubbins PA. Ultrasound demonstration of bowel wall thickness in inflammatory bowel disease. Clin Radiol 1984; 35: 227-31.
25. Arienti V, Campieri M, Boriani L et al. Management of severe ulcerative colitis with the help of high resolution ultrasonography. Am J Gastroenterol 1996; 91: 2163-9.

26. Maconi G, Sampietro GM, Cristaldi M et al. Preoperative characteristics and postoperative behavior of bowel wall on risk of recurrence after conservative surgery in Crohn's disease: a prospective study. Ann Surg 2001; 233: 345-52.

27. Parente F, Sampietro GM, Molteni M et al. Behaviour of the bowel wall during the first year after surgery is a strong predictor of symptomatic recurrence of Crohn's disease: a prospective study. Aliment Pharmacol Ther 2004: 20: 959-68.

28. Brahme F, Lindström C. A comparative radiographic and pathological study of intestinal vasoarchitecture in Crohn's disease and in ulcerative colitis. Gut 1970; 11: 928-40.

29. Spalinger J, Patriquin H, Miron MC et al. Doppler US in patients with crohn disease: vessel density in the diseased bowel reflects disease activity. Radiology 2000; 217: 787-91.

30. Esteban JM, Maldonado L, Sanchiz V et al. Activity of Crohn's disease assessed by colour Doppler ultrasound analysis of the affected loops. Eur Radiol 2001; 11: 1423-8

31. Miao YM, Koh DM, Amin Z et al. Ultrasound and magnetic resonance imaging assessmentof active bowel segments in Crohn's disease. Clin Radiol 2002; 57: 913-8.

32. Futagami Y, Haruma K, Hata J et al. Development and validation of an ultrasonographic activity index of Crohn's disease. Eur J Gastroenterol Hepatol 1999; 11: 1007-12.

33. Maconi G, Parente F, Bollani S et al. Abdominal ultrasound in the assessment of extent and activity of Crohn's disease: clinical significance and implication of bowel wall thickening. Am J Gastroenterol 1996; 91: 1604-9.

34. Bozkurt T, Rommel T, Stabenow-Lohbauer U. Sonographic bowel wall morphology correlates with clinical and endoscopic activity in Crohn's diesease and ulcerative colitis. Eur J Ultrasound 1996; 4: 27-33

35. Bierig SM, Jones A. Accuracy and cost comparison of ultrasound versus alternative imaging modalities, including CT, MR, PET, and angiography. Journal of Diagnostic Medical Sonography 2010; 25: $138-44$

36. Horsthuis K, Bipat S, Bennink RJ et al. Inflammatory bowel disease diagnosed with US, MR, scintigraphy, and CT: meta-analysis of prospective studies. Radiology 2008; 247: 64-79.

37. Ødegaard S, Gilja OH, Matre K. Innføring i abdominal ultrasonografi. Bergen: Fagbokforlaget, 2009.

Manuskriptet ble mottatt 5.2. 2009 og godkjent 27.7. 2010. Medisinsk redaktør Trine B. Haugen. 